\title{
Innovating consultative authoritarianism: Internet votes as a novel digital tool to stabilize non-democratic rule in Russia
}

new media \& society

(C) The Author(s) 2016

Reprints and permissions: sagepub.co.uk/journalsPermissions.nav DOI: I0. I |77/|46 |4448 |6675444 nms.sagepub.com

(SSAGE

\section{Florian Toepfl}

Free University of Berlin, Germany

\begin{abstract}
Extant research on the consequences of the Internet for non-democratic politics has focused on how oppositional activists leverage new digital tools. By contrast, still, relatively little is known about how authoritarian elites proactively deploy digital technologies to legitimize their rule. This article contributes to filling this gap by scrutinizing one highly innovative tactic that has recently been adopted repeatedly by Russia's ruling elites: the organization of 'Internet votes' to staff advisory bodies to the government. In contrast to online petitions, online votes are aimed at aggregating citizen preferences not on issues but on candidates, that is, on individuals who later act as political representatives. The article presents an in-depth case study of the first such Internet vote conducted in Russia in 2012. It concludes that ruling elites deployed the tool swiftly to (I) disempower oppositional activists and (2) convey to the mass public the image of a transparent, accountable and responsive government.
\end{abstract}

\section{Keywords}

Authoritarianism, digital repertoires, hybrid regimes, non-democratic politics, participation, political communication, Russia

\section{Corresponding author:}

Florian Toepfl, Institute for Media and Communication Studies, Free University of Berlin, Garystrasse 55, Berlin 14195, Germany.

Email: f.toepfl@fu-berlin.de 
Over the past decade, a vibrant body of academic literature has emerged on the political consequences of the Internet for non-democratic politics. However, as a number of scholars have recently lamented (Greitens, 2013; Gunitsky, 2015; Oates, 2013; Pearce, 2015; Renz and Sullivan, 2013), this research has largely focused on either (1) how oppositional activists leverage new digital tools to challenge authoritarian rule or (2) how authoritarian elites suppress and censor online dissent. By contrast, there has been relatively 'little discussion of how states actively use the internet to expand their communicative power' (Oates, 2013: 7; Greitens, 2013). This gap in research is particularly unfortunate since political scientists have recently highlighted the key role that quasidemocratic 'institutions for political participation' play in the unexpected 'resilience' of contemporary authoritarian regimes (Nathan, 2003: 7; see also He and Thogersen, 2010; He and Warren, 2011; Lagacé and Gandhi, 2015; Truex, 2014). In this context, even consideration of the emergence of new types of 'consultative' or 'deliberative' authoritarian regimes has been suggested (He and Warren, 2011: 273).

This article seeks to contribute to filling this gap by placing under close scrutiny one highly innovative, digitally enabled strategy that has recently and repeatedly been adopted by Russia's ruling elites: the organization of 'Internet votes' to staff advisory bodies to the authoritarian government. By 'Internet votes', I intend in this study specifically the online aggregation of citizen preferences for candidates to staff political bodies performing administrative or advisory functions. In contrast to the more widely scrutinized participatory tools of online petitions or polls (Gunitsky, 2015; Jiang and Xu, 2009), Internet 'votes' are thus aimed at the aggregation of preferences, not on issues but on candidates, that is, on human beings who then act as political representatives. In contrast to traditional elections (for the role of elections under authoritarian rule, consider He and Warren, 2011; Lagacé and Gandhi, 2015; for experiments with e-voting in authoritarian contexts, consider Yard, 2010), Internet votes are not directed at appointing the highest legislative, judicative or executive organs of state, but at staffing advisory or administrative bodies. They are merely a participatory tool. Internet votes, so defined, have been initiated by the Russian regime since 2012 to fill positions in a wide range of advisory bodies to the government, including the Civic Chamber of the Russian Federation (BBC.com, 2014¹), the Expert Council to the Government of the Russian Federation (Open.gov.ru, 2015a $\mathrm{a}^{1}$ ), the Public Council of the Ministry of Health (Medpro. ru, 2013 ${ }^{1}$ ) and the Public Chambers of the Municipal Divisions of the Moscow Federal District (Perezagruzkaopmo.rf, 2014¹).

Despite their repeated adoption by the Russian regime, Internet votes as a new participatory tool have not yet been scrutinized in extant research on the consequences of the Internet for authoritarian politics (for overviews of this literature, consider Greitens, 2013; Gunitsky, 2015; He and Warren, 2011; Pearce, 2015). The key research questions that this exploratory study puts forth can be formulated as follows: Have the Internet votes recently held in Russia actually empowered oppositional forces, or have they instead played into the hands of the country's ruling elites? And, if the latter is the case, then why and how can Internet votes - as seemingly inherently democratic participatory mechanisms - contribute to the stabilization of authoritarian rule? In order to answer these questions, this article adopts a single 'revelatory case' (Yin, 2014: 52) study design. To be specific, it scrutinizes the case of the first such Internet vote initiated by the 
Kremlin, in summer 2012. This vote was aimed at appointing new members to a highprofile advisory body, the President's Council on the Development of Civil Society and Human Rights (PCHR, Sovet pri Presidente RF po razvitiyu grazhdanskogo obshchestva $i$ pravam cheloveka). It was conducted between 1 and 15 September 2012 on the Council's website, with every user entitled to support each of the 83 candidates with a maximum of one vote. According to official data, 108,000 citizens visited the site and cast 420,000 votes (PCHR, 2012d). A list of the 39 most-voted-for candidates was later presented to President Vladimir Putin, who decided, allegedly spontaneously, to appoint all 39 candidates on the list and thus expand the Council from the previous 30 to nearly 70 members.

With regard to the methods of data collection, the analysis is grounded in extensive document analysis of mass media reports, government documents, think tank papers and social media accounts of activists. ${ }^{1}$ These documentary data were supplemented with additional information generated from personal interviews with two Russian experts and four key participants. ${ }^{1}$ By drawing on these data, the analysis concludes that the opening of the voting website as an online participatory space was swiftly deployed by Russia's ruling elites (1) to disempower a group of widely respected oppositional activists who had previously served on the Council and to (2) convey to the mass public the image of transparent, accountable, and responsive government. In order to flesh out this line of argumentation, the remainder of the article is structured as follows: The next section reviews the extant literature on consultative authoritarianism as a regime type and on authoritarian elites' proactive use of new digital participatory tools. The subsequent section provides background information on the functioning of the PCHR as a co-opted advisory council within Russia's consultative authoritarian regime. A further section on methods is then followed by a section presenting the findings of the case analysis. The final part discusses the specifics of Internet votes as a novel addition to the repertoire of digital participatory tactics available to authoritarian leaders in the 21 st century.

\section{Consultative authoritarianism: functions and risks of authoritarian institutions}

Since the end of the Cold War, authoritarian regimes across the globe have been increasingly adopting a broad range of participatory institutions that are typically associated with democracies, including elections, parliaments, parties, consultative forums and deliberative assemblies (He and Warren, 2011; Lagacé and Gandhi, 2015; Levitsky and Way, 2010). However, even though these institutions do now formally operate within many authoritarian regimes, they usually function 'at the discretion of rulers and their supporting elites' (Lagacé and Gandhi, 2015: 278). These empirical observations have sparked an intense debate within the discipline of political science on the question of how to conceptualize new forms of authoritarian rule. Scholars have proposed, for instance, new types of 'competitive' (Levitsky and Way, 2010), 'deliberative' (He and Warren, 2011) and 'consultative' (He and Warren, 2011; Truex, 2014) authoritarianism. In this context, the concept of consultative authoritarianism (He and Warren, 2011; Truex, 2014) has been specifically deployed to emphasize, and scrutinize, how authoritarian regimes have started to vigorously encourage controlled forms of citizen input. He 
and Warren (2011), for instance, have defined consultative authoritarianism as 'a form of rule in which power holders use communication to collect the preferences of those their decisions will affect' (p. 273). Unlike in democracies, however, citizen participation in consultative authoritarianism is not followed by decisions of democratically elected representatives, but by decisions of unelected - or not competitively elected - rulers ( $\mathrm{He}$ and Warren, 2011). In order to collect information from citizens, consultative authoritarian rulers typically create a broad range of 'input institutions' (Nathan, 2003: 14). In contemporary China, for instance, draft legislation is now routinely posted online for public comment, citizens and experts are invited to public legislative hearings and party and government agencies maintain offices for citizen complaints (He and Thogersen, 2010; He and Warren, 2011; Nathan, 2003). The authoritarian regimes of Singapore, Malaysia and Vietnam feature similar consultative elements (He and Warren, 2011).

Likewise, the Russia of the early 2010s could be considered an instance of an authoritarian polity adopting a broad spectrum of consultative tactics. Throughout the 2000 s, the regime encouraged citizen participation via a variety of input institutions, including even regular, although not particularly competitive, elections at the national level (Levitsky and Way, 2010: 186-201). In 2011, however, these elections prompted a massive wave of street protests against alleged electoral fraud. Russia's political elites reacted with a shift towards more 'harsh authoritarianism' (Shevtsova, 2015: 23). Important policy changes under way at the time of the Internet vote, scrutinized in this study, included a resolute campaign against recalcitrant non-government organizations (NGOs) and new limits on Internet content and foreign ownership of media companies (Shevtsova, 2015: 30-31). While the Russian authoritarian regime thus clearly restricted some forms and channels of citizen input, it continued, in contrast, to vigorously encourage others. Most remarkably, a high-profile initiative referred to as 'Open Government' (Otkrytoe pravitelstvo) aimed, according to its mission statement, to 'secure the efficient co-operation between authorities and society' and to include 'civil society and business in political decision-making' (Open.gov.ru, 2015b ${ }^{1}$ ). This initiative featured, among others, programmes labelled as open data (Otkrytye dannye), open state purchasing (Otkrytye goszakupki), citizen budgets (byudzhet dlya grazhdan), open state companies (Otkrytye goskompanii) and public councils (Obshchestvennye sovety) (Open.gov.ru, 2015b). At the time of research, the PCHR was thus only one among a flurry of public councils operating as input institutions within Russia's consultative authoritarian regime - albeit one of the most prominent.

Why are such input institutions created by authoritarian elites? As He and Warren (2011) have argued with specific regard to deliberative practices, authoritarian elites are able to pursue at least five goals: (1) co-opting oppositional and pro-regime elites, (2) gathering information about society, (3) opening up forums for exchange with business elites, (4) credibly increasing transparency of government and (5) deflecting responsibility for unpopular decisions (for similar lists of functions, consider Lagacé and Gandhi, 2015; Nathan, 2003; Truex, 2014). On a related note, Lagacé and Gandhi (2015) have argued that authoritarian elites are able to use participatory institutions in order to 'manage their relations' (p. 280) with four groups of actors: (1) pro-regime elites, (2) oppositional elites, (3) ordinary citizens opposing the regime and (4) the mass public. However, while authoritarian elites may benefit from creating input institutions, there are also risks. The key dilemma is that institutions, in order to credibly fulfil their purposes, 
necessarily also have to - at least to some degree - constrain the actions of ruling elites (He and Warren, 2011; Lagacé and Gandhi, 2015). Meaningful and credible elections, for instance, must imply at least a small chance that autocrats could lose them. Additional risks come with electoral fraud and manipulation, since the latter can 'provide a focal point for the opposition and masses to rally around' (Lagacé and Gandhi, 2015: 286).

\section{Digital participatory tools deployed by authoritarian elites: three types}

Partly by referring to this broader literature on authoritarian institutions, recent studies on the proactive use of digital technologies by authoritarian elites have scrutinized primarily three types of participatory tools. The first type of online participatory space invites netizens to monitor the implementation of selected policies or lower-level officials (see, for example, Jiang and Xu, 2009; Noesselt, 2014; Toepfl, 2012). Key aims here are to make some areas of government more transparent, to increase levels of accountability among lower-level officials and to step up the efficiency of the bureaucracy. These goals were furthered, for instance, by the citizen complaint boxes that were in place on virtually all of the 31 Chinese provincial government portals scrutinized by Jiang and $\mathrm{Xu}$ (2009). On $61 \%$ of these portals, a high degree of activity was observed, that is, dozens of contributions 'displayed online every month as a result of steady contributions from users' (Jiang and Xu, 2009: 179). With regard to Russia, it has been shown how citizen complaints on blogs (Toepfl, 2012) and the Twitter accounts of officials (Renz and Sullivan, 2013) can serve similar purposes.

A second type of online participatory space created by authoritarian elites encourages citizens to discuss planned policies and government measures, and even draft laws (Gunitsky, 2015; Jiang, 2010). Key functions of these spaces are to discover possible solutions to issue-specific problems and to gather information about the concerns of ordinary citizens and stakeholders. A primary example of this type of tool is the online consultation organized by the Chinese authorities with regard to a proposed revision of the health system (Balla, 2014; Balla and Liao, 2013). As Balla and Liao (2013) found, it was 'common' for the approximately 30,000 comments published on this platform 'to address substantive issues in great depth, as well as express negative assessments of government decisions. This suggests that online consultation holds promise as an instrument of governance reform' (p. 101; for similar lines of argumentation with regard to Russia, see Renz and Sullivan, 2013; Toepfl, 2012).

Third, many authoritarian governments have opened up participatory spaces that aggregate citizen preferences on specific issues online (Gunitsky, 2015; Jiang and Xu, 2009: 186). The key function of these tools is to gauge the intensity of support for, or resistance to, planned measures or policy changes. In 2007, for instance, more than $80 \%$ of Chinese provincial government portals featured multiple-choice opinion polls, with approximately one-third of these portals regularly featuring this tool and with results displayed online (Jiang and $\mathrm{Xu}, 2009$ : 186). Within Russia's relatively more open authoritarian system, the government even operated an online collective petitioning platform, launched in 2013 under the label 'Russian Public Initiative' (Gunitsky, 2015: 48). 
This study aims to extend this literature on how authoritarian elites adopt digital participatory tools, primarily at two points. First, while a small body of research has scrutinized the three types of participatory spaces distinguished above (see, for instance, Balla and Liao, 2013; Jiang, 2010; Jiang and Xu, 2009; Truex, 2014), this is the first study of how authoritarian elites specifically deploy Internet votes as a novel participatory mechanism. Second, recent research of online participatory spaces in authoritarian contexts has largely relied on the content analysis of websites (Balla and Liao, 2013; Jiang and $\mathrm{Xu}, 2009$ ) or on surveys of or experiments with citizens (Balla, 2012; Truex, 2014). By contrast, this study adopts the case-study method, grounding its findings in extensive document analysis and in-depth interviews with experts and key participants involved in the design of the participatory space. This approach facilitates the addressing of a distinct set of research questions, including, for instance, those regarding the motives and strategies of key actors involved in the design and implementation of the participatory tool, or on the narratives about the participatory process as they are presented to the mass public via official, elite-controlled media. Before the case analysis is pursued, the next section provides some background knowledge about the PCHR.

\section{The PCHR as an input institution within Russia's consultative authoritarian regime}

At the time of research, the PCHR played a highly ambiguous role within Russia's consultative authoritarian regime. In organizational terms, the body of approximately 30 members was part of the Presidential Administration. The president thus had the formal right to appoint whomever he wished to the Council. Typically, the president would invite both, pro-regime and sharply oppositional activists to work on the Council. In line with the literature on authoritarian institutions (Lagacé and Gandhi, 2015; Nathan, 2003; Truex, 2014), the PCHR was thus arguably directed at serving at least three purposes for Russia's ruling elites (Foreign Policy Centre, 2013; PCHR, $2014^{1}$ ). First, the Council enabled ruling elites to gather information about human rights violations in the country, about oppositional elites' and activists' demands in this policy area, and about possible ways of addressing the grievances. Second, the PCHR could be used as an instrument to co-opt both pro-regime and oppositional elites by granting them a seat in the president's advisory council. Third, the PCHR arguably also helped co-opt the Russian mass public by highlighting the president's commitment to human rights and by showcasing the support he enjoyed even among widely respected oppositional figures.

With regard to the Internet vote scrutinized in this study, four groups of actors involved in this participatory undertaking can be distinguished, with whom Russia's ruling elites were thus potentially able to 'manage their relations' (Lagacé and Gandhi, 2015: 280): (1) pro-regime elites and (2) oppositional elites as members of the Council, (3) highly politically engaged citizens who could be expected to participate as voters and (4) the mass public who followed the Internet vote exclusively through the country's mainstream, elite-controlled mass media. Drawing on the analytical framework laid out in the previous pages, the findings of the case study are presented in the following as responses to three more narrowly specified research questions: Did the introduction and the design 
of the Internet vote serve the aims of Russia's ruling elites, and, if so, then how (RQ1)? Did the implementation of the Internet vote serve Russia's ruling elites, and, if so, then how (RQ2)? And did the narrative disseminated by mainstream elite-controlled media serve Russia's ruling elites, and, if so, then how (RQ3)?

\section{Methods of data collection and analysis}

RQ1 and RQ2 require reconstruction of the motives, opportunities, and actions of the key political actors involved in the Internet vote over time. To accomplish this task, the case analysis draws on a wide range of documentary sources, including government documents, reports authored by both Western and Russian experts, news media articles and social media accounts of participants. Within the semi-controlled Russian media environment (cf. Oates, 2013; Renz and Sullivan, 2013; Toepfl, 2011), particularly niche oppositional media and social media, albeit reaching only very small audiences, facilitated the relatively unhampered dissemination of a wealth of real-time commentary from the political leadership, oppositional activists, experts and anonymous informants within the Kremlin. These publicly available data were complemented by information generated in in-depth interviews with four key participants in the events (oppositional activists) and two Russian experts. ${ }^{1}$ The aim of data collection was thus to consider the widest available range of sources and then 'triangulate' the data obtained on the two research questions in order to develop 'converging lines of inquiry' ('data triangulation', Yin, 2014: 122; for a detailed description of the research procedures adopted, see the Online Supplementary File).

RQ3 required the reconstruction of the narrative about the Internet vote as it reached the Russian 'mass public' (Lagacé and Gandhi, 2015: 280). A key feature of the Russian semi-controlled media landscape, at the time of this research, was that it could be divided into at least two spheres: (1) a powerful sphere of elite-controlled official media, spearheaded by the three leading national TV channels, First Channel, NTV, and Rossiya 1, and (2) a marginalized sphere of oppositional mass and social media (see Oates, 2013; Toepfl, 2011, 2012, in press). In the first sphere of elite-controlled media, news was produced in close alignment with Russia's ruling elites, with weekly strategic meetings between Kremlin staff and leading editors being reported (Bykhovskaya, 2011). Individual stories could be dropped immediately, according to journalists working in these media outlets, in response to phone calls from the presidential administration (Bykhovskaya, 2011). By contrast, Internet content in Russia was not systematically filtered, in sharp contrast to that in China (Oates, 2013). Regime-critical information was thus freely accessible online. Yet, official mass media were overwhelmingly dominant with regard to audience reach. In June 2012, for instance, $71 \%$ of Russians said in a poll that they relied primarily on elite-controlled national TV channels for obtaining their news (Levada, 2014: 123). By comparison, only 16\% said they relied primarily on the Internet, and only approximately $1 \%$ said they relied primarily on private newspapers or the radio (Levada, 2014: 123). The radio station 'Echo Moscow', for instance, a flagship outlet of the marginalized sphere of regime-critical oppositional media, had a weekly audience of only 5\% of citizens (Echo Moscow, 2015). The oppositional TV channel Dozhd was only followed by 2\% (Levada, 2014: 125). 
In order to establish what the 'mass public' (Lagacé and Gandhi, 2015: 280) was most likely to learn about the Internet vote, the analysis aims to reconstruct the narrative and facts about the event as they were presented on the three leading elite-controlled TV channels, which were used by approximately $71 \%$ of Russian citizens as their primary source of news. To conduct this analysis, all news broadcasts about the Internet vote aired on First Channel's main news programme Vremya were identified via keyword searches ('Council' and 'Human Rights') on the channel's website, where a complete database of the transcripts of all the broadcasts is available. Similar keyword searches were carried out on the websites of the two other leading elite-controlled TV channels, NTV and Rossiya 1, where, however, not all items broadcast are published. This resulted in a corpus of approximately 30 news broadcasts, typically of between 30 seconds and 6 minutes in length. From this corpus, the basic narratives presented below were reconstructed in an iterative process of close reading and re-reading.

\section{Findings}

\section{How the introduction of the Internet vote served Russia's ruling elites}

Within Russia's consultative authoritarian regime, the PCHR served Russia's ruling elites in pursuit of a number of critical tasks (see above). These gains were, however, imperilled in early 2012, when 11 of the 38 council members resigned from the Council, with many of the dropouts saying they left in protest against the new laws that the Kremlin was pushing through to curb the street protests (Gazeta.ru, 8 June 2012 ${ }^{1}$ ). Approximately a dozen new members needed to be recruited. However, appointing activists to the PCHR had always been a highly delicate task for the Kremlin, even in more favourable political climates, for at least two reasons: (1) oppositional activists could publicly reject an official invitation by the president, and (2) oppositional activists already serving on the Council could resign in protest if specific pro-regime figures were appointed (cf. Alexeyeva, 2015, personal communication). Therefore, the intricate task of recruiting new members had traditionally been performed by the Council's chairman in a series of informal, non-public negotiations with members of the Council, officials in the Presidential Administration and potential candidates (Krivenko, 2015, personal communication; Vedomosti, 22 June 2012). It was this prior recruitment procedure that, in June 2012, the Kremlin decided to substitute with a new participatory mechanism: an 'Internet vote' (Vedomosti, 22 June 2012). The official rationale for this decision, as provided by the deputy head of the Presidential Administration, Vyacheslav Volodin, was that 'more democratic mechanisms', not 'secret consultations', were necessary to form the Council (Kommersant, 23 June 2012; Izvestiya, 22 June 2012a). The recruitment of new members to the PCHR was meant to become more 'contemporary, public, transparent, and modern' (Kommersant, 23 June 2012).

Immediately after the Kremlin's plans were announced, however, oppositional elites in the Council began to publicly campaign against the vote. A group of four prominent council members resigned with reference to the new 'quasi-democratic selection rules' (Gazeta.ru, 26 June 2012; Echo Moscow, 26 June 2012). The group was headed by one of Russia's most prominent oppositional activists, Lyudmila Alexeyeva, aged 85 years, a 
veteran of the Soviet dissident movement and co-founder of the Moscow Helsinki Group. Opposition also came from the Council's chairman, Mikhail Fedotov, who publicly stated that 'the Russian soccer team was not selected by such a democratic procedure either' (Echo Moscow, 22 June 2012). The rationale behind the resistance of oppositional elites was obvious: They were convinced that any type of Internet vote implemented under the supervision of the Kremlin would be widely open to manipulation and would, beyond any doubt, be exploited by the Kremlin in order to pursue strategic aims (Alexeyeva, 2015, personal communication; Echo Moscow, 22 June 2012). From the very beginning, oppositional council members reckoned that the introduction of the 'Internet vote' was primarily directed at curbing their influence on the selection of new members (Krivenko, 2015, personal communication; Alexeyeva, 2015, personal communication). Despite these initial protests, however, chairman Fedotov soon gave up his opposition after rumours had spread that the Kremlin was considering removing him from office (Echo Moscow, 27 June 2012; Echo Moscow, 28 June 2012).

On the Council's website (PCHR, 2012a), the design of the new participatory mechanism, agreed upon between Fedotov and the Kremlin, was later presented as follows, in five stages:

1. Nominating candidates. Within a time period of 30 days, potential candidates are nominated by, among others, NGOs and council members through the Council's website.

2. Shortlisting candidates. From these nominations, a working group in the Council selects a list of candidates allowed to run in the vote, based on their meeting the 'requirements' for the position.

3. Voting. Within a 15-day period, Internet users can cast up to one anonymous vote for each candidate, with results updated on the website in real time.

4. Reporting results. The Council chairman reports the results to the president and recommends at least three candidates for each vacant position.

5. Appointment of candidates by the president. No rules specified.

At least four points can be concluded from this brief analysis of the introduction and design of the Internet vote. First, the Kremlin had to push through the Internet vote against the resolute resistance of oppositional elites serving on the Council who feared losing their influence on selecting new members. Second, the Kremlin succeeded in pushing through an easily malleable participatory design; most importantly, the participatory rules specified no safeguards to guarantee effective and independent monitoring of the vote. Third, the Kremlin managed to introduce this type of participatory tool without prompting a mass exodus of members from the Council or a consistent boycott of the vote by oppositional elites. Fourth, the Kremlin obviously accomplished these successes by granting a small number of formal concessions to oppositional council members, according to which the latter retained at least some influence on the selection of new council members (cf. Krivenko, 2015, personal communication). Most notably, in Stage 2, sitting council members were empowered to reject nominated candidates, and, in Stage 4, the chairman was not formally obliged to align his list of recommended candidates with the results of the vote. The next section probes the 
degree to which these formal concessions were later hewn by the Kremlin in implementing the Internet vote.

\section{How the implementation of the Internet vote served the Kremlin}

As envisaged in Stage 1 of the participatory design, 189 candidates were proposed through the Council's website between 15 July and 15 August 2012 (Izvestiya, 16 July 2012). Of these 189 candidates, a working group of sitting council members then selected 83 candidates to be shortlisted and included in the Internet vote. These decisions had to be made, as vaguely formulated in the participatory rules, based on the candidates meeting not-further-specified 'requirements' (trebovaniya) for specific issue areas (PCHR, 2012a; Izvestiya, 27 August 2012). The shortlist presented by the Council triggered a heated public controversy, with some candidates complaining that they had been rejected for personal reasons. One rejected candidate, Aleksandr Brod, even declared a hunger strike (Izvestiya, 3 September 2012). Yet, the shortlist composed by the council members remained largely unchanged.

Entering into Stage 3, the Internet vote was conducted between 1 and 15 September 2012. It was implemented and supervised by the Kremlin via the state-owned news agency RIA Novosti (Golos, 2012). Through a voting tool embedded into the official website of the PCHR, each Internet user was entitled to support each of the 83 candidates with up to one vote (PCHR, 2012c). According to official data, 108,000 citizens participated and cast 420,000 votes (PCHR, 2012d). To prevent users from voting twice for a candidate, the tool registered their IP addresses and saved cookies into their browsers. Access to the corresponding log files, however, was not granted to independent monitoring organizations (Udot, 2015, personal communication). Most notably, the voting tool did not provide a real-time count of the absolute number of votes cast for each candidate. By contrast, it showed only the real-time percentage values of the votes that each candidate had allegedly received (PCHR, 2012b). This was a key weakness of the tool, as Roman Udot (2015, personal communication), an expert who observed the vote for the Russian election monitoring NGO Golos, argued. The absence of real-time, absolute vote-counts afforded the Kremlin with close to unlimited opportunities to manipulate the vote's outcome.

Given the regime's widely known track record of manipulating traditional offline elections (Oates, 2013; Shevtsova, 2015), it appeared common sense and beyond any doubt to the members of the Russian opposition that the Kremlin would not hesitate to also rig the Internet vote in order to pursue its strategic goals (Alexeyeva, 2015, personal communication; Krivenko, 2015, personal communication). Most straightforwardly, the Kremlin's webmasters would have had the opportunity to simulate the slight movement of percentage values for each candidate, without even taking the votes cast by netizens into account. Even if they had committed this most straightforward type of electoral fraud, Russia's oppositional forces would have had no chance to uncover the manipulations (Udot, 2015, personal communication). The only means of monitoring the vote available to Golos was to systematically harvest data from the front end of the voting platform, that is, to trace shifts in the percentage values shown for candidates minute by minute. These data provide, for instance, evidence that the vote count of a Kremlin-friendly candidate that had 
been fluctuating around $37 \%$ for several days leapt to a winning $43 \%$ within only 2 hours on the last day of the vote (Novaya Gazeta, 1 October 2012). As Golos observer Udot (2015, personal communication) notes, this may not be conclusive proof of manipulation. Yet, observing such a massive leap on the basis of real voter behaviour was as likely as 'winning the lottery ten times in a row' (Udot, 2015, personal communication).

In Stage 4, Chairman Fedotov was supposed to prepare a 'report' for the president about the results of the vote. According to Fedotov's own account, a conflict soon emerged again between him and the deputy head of the Presidential Administration, Vyacheslav Volodin (Izvestiya, 25 October 2012). While Fedotov intended to submit a list of candidates who he personally recommended, Volodin insisted that Fedotov hand over to the president a document labelled as a briefing (informatsiya) that simply reproduced the most-voted-for candidates (Izvestiya, 25 October 2012; Krivenko, 2015, personal communication). Ultimately, Fedotov also had to back down in this respect. He handed over a list with the 39 most-voted-for candidates to President Putin. In addition, he recommended eight further candidates (Gazeta.ru, 8 November 2012), but none of his eight suggestions was accepted by the president. By contrast, President Putin decided, allegedly 'spontaneously', to appoint all 39 candidates on Fedotov's electoral list and expand the PCHR from 40 to more than 60 seats (First Channel, 1 November 2012; NTV, 1 November 2012; Rossiya 1, 1 November 2012). Two weeks later, Putin even appointed Aleksandr Brod to the Council, an activist who had been most fiercely rejected and excluded from the vote by the sitting council members in Stage 2, because he had embezzled grant money in one of his projects (Echo Moscow, 17 November 2012; Alexeyeva, 2015, personal communication).

From this in-depth analysis of the implementation of the Internet vote, four conclusions can be drawn. First, the Kremlin implemented a voting tool that simulated transparency by logging users' IP addresses and publishing real-time percentage results. Yet, de facto, the tool posed virtually no limits to the manipulation of the vote's outcome by the Kremlin, while it offered close to no opportunities for oppositional forces to reveal potential manipulations. Second, the Kremlin did not act upon the vaguely formulated concessions made to oppositional elites in the agreed-upon participatory rules. Third, the Kremlin consistently justified its disregard of oppositional elites' recommendations by pointing to the results of the quasi-democratic and transparent Internet vote. To summarize, with the introduction of the Internet vote, oppositional elites lost - as they had feared from the very beginning - virtually all influence on the selection of new council members.

\section{How the narrative disseminated by elite-controlled TV served ruling elites}

What did ordinary Russians learn about the Internet vote from the country's three leading elite-controlled TV channels? As a qualitative analysis of the news coverage of these channels reveals, the Internet vote was put on the news agenda by the three elite-controlled channels mainly on four occasions. On those four occasions, the narrative disseminated about the vote by the three TV channels scarcely featured any differences, but ran broadly parallel. The first time that the Internet vote made it into the official news was on 22 June 2012. On this day, Russia's elite-controlled TV presented the council chairman, 
Fedotov, as the author of the idea that the Council should be formed in the future in accordance with 'new principles', that is, based on an Internet vote (First Channel, 22 June 2012; see also NTV, 22 June 2012; Rossiya 1, 22 June 2012). By contrast, Fedotov's and other council members' fierce protest against the introduction of the vote was not mentioned. Likewise, the reasons why new members needed to be appointed to the Council were omitted (see, for instance, NTV, 22 June 2012; Rossiya 1, 22 June 2012).

A further occasion that the Internet vote made it on the official news agenda was on 1 November 2012. In the news broadcast that day (see, for instance, First Channel, 1 November 2012), Chairman Fedotov was shown handing over a report to President Putin. As the voiceover on First Channel (1 November 2012) explained, Fedotov was, at that moment, recommending to the president the most popular new candidates for the Council as they emerged from an Internet vote. Fedotov's resistance to submitting this purely electoral list and his failed attempt to suggest alternative candidates were not mentioned. By contrast, as the voiceover on First Channel announced (1 November 2012), Fedotov found it hard to choose between even the three most successful candidates in the Internet vote, since all of them appeared 'worthy'. President Putin, however, solved this problem by suggesting the appointment of all 39 candidates on the list, since these, as Putin explained to the TV audience, 'are the people voted by the majority of Internet users, independently of whether certain people in the administrative-executive state organs may like them or not'.

To summarize, the coverage of Russia's state TV channel portrayed (1) council members as the initiators of the Internet vote while not mentioning their resolute resistance,

(2) Russia's ruling elites as largely passive observers while not explicating their central role in shaping and implementing the vote, (3) the voting mechanism as highly transparent and secure while not touching upon its weaknesses, and (4) rank-and-file activists as highly empowered voters who created and legitimized the new Council while being silent about potential manipulations. In a nutshell, the TV narrative served the purposes of Russia's ruling elites by systematically overstating the participatory influence of oppositional elites and ordinary activists while consistently downplaying the decisive role of the Kremlin.

\section{Discussion}

The case study from Russia presented in this article was the first to investigate the complex ways in which Internet votes to staff advisory bodies - as allegedly inherently democratic participatory mechanisms - can be swiftly deployed by authoritarian elites to further their strategic goals. In order to do so, the study placed under close scrutiny the first such Internet vote held in Russia in 2012 aimed at appointing new members to the PCHR.

\section{The Internet vote to the PCHR: empowering citizens or power-holders?}

As demonstrated in the case analysis, the Internet vote, as it was implemented, featured three key characteristics. First, it posed close to no limits for Kremlin staff to manipulate its results. Second, it offered virtually no opportunities for oppositional forces to reveal potential manipulations. Third, the vote could be implemented in a socio-political context 
in which mainstream mass media did not critically interrogate the entire participatory undertaking, but consensually disseminated a narrative about the event that exclusively served the strategic goals of Russia's power-holders. As a consequence, from the perspective of ruling elites, introducing an Internet vote as an additional participatory mechanism came with virtually no risks, but offered a variety of opportunities to swiftly optimize their relationships with different segments of the population (He and Warren, 2011; Lagacé and Gandhi, 2015; Truex, 2014).

As Lagacé and Gandhi (2015) have argued, authoritarian elites can establish participatory institutions in order to 'manage their relations' (p. 280) with four groups of actors: (1) pro-regime elites, (2) oppositional elites, (3) ordinary citizens opposing the regime, and (4) the mass public. These four key groups were also involved in the Internet vote to the PCHR: (1) regime-loyal and (2) oppositional elites as sitting and prospective members of the Council, (3) highly politically engaged citizens as voters, and (4) a mass public who followed the vote exclusively through elite-controlled media. By comparison with the previous selection procedure of informal negotiations, Russia's ruling elites were able to tweak their relationships with primarily two of these groups: oppositional elites and the mass public. As the in-depth analysis demonstrated, the Internet vote enabled Russia's ruling elites to deprive oppositional elites of virtually all their previous influence on recruiting new members. Moreover, the Russian mass public, who learnt about the entire participatory undertaking exclusively from elite-controlled media, could be presented with a sophistically tailored narrative about the event that unambiguously bolstered the legitimacy of ruling elites.

By contrast, it is disputable whether the Internet vote also helped Russia's ruling elites to increase their legitimacy within the third group, that is, among the 108,000 citizens who actually participated in the vote (PCHR, 2012). Within the semi-controlled Russian media environment, the overwhelming majority of these politically engaged citizens, who followed the Council's work actively, were most likely also following the coverage of oppositional mass media (Oates, 2013; Toepfl, 2011). Russia's oppositional media, however, as the sources cited in the case analysis vividly illustrate, covered the Internet vote in a highly critical manner, also decrying the hypocritical role that the Kremlin took on as a behind-the-scenes manager of the vote (Novaya Gazeta, 1 October 2013). Against this backdrop, some Russian experts even argued that the Internet vote as a participatory tactic was directed by the Kremlin - somewhat paradoxically - not primarily at participants but at non-participants (Stechkin, 2015, personal communication; Novaya Gazeta, 1 October 2013). According to this very plausible line of argument, by implementing the Internet vote, Russia's ruling elites aimed to increase their legitimacy not primarily among the 108,000 netizens who voted online, but among the more than hundred times larger mass public of tens of millions of citizens, who learnt about the entire undertaking exclusively from elite-controlled TV.

\section{Expanding the repertoire of digital participatory tools of authoritarian leaders}

Extant research on the consequences of the Internet for politics has largely focused on how oppositional activists leverage new digital tools to challenge authoritarian rule 
(Greitens, 2013; Gunitsky, 2015; Oates, 2013; Pearce, 2015). However, with the rise of the Internet, in parallel to a new 'digital repertoire of contention' (Earl and Kimport, 2011: 177) adopted by activists, a new repertoire of digital participatory tools deployed by authoritarian elites also appears to have emerged. Within this repertoire, the Internet votes exemplified in this article can be considered a recent innovation. How do Internet votes compare with previously studied types of participatory tools, such as, for instance, online spaces that invite citizens to monitor lower-level officials (Jiang and $\mathrm{Xu}, 2009$; Noesselt, 2014; Toepfl, 2012), to deliberate on planned policies (Gunitsky, 2015; Jiang, 2010), or to voice their preferences on specific issues? (Gunitsky, 2015; Jiang and Xu, 2009: 186). As has been argued in the literature on authoritarian institutions (He and Warren, 2011; Lagacé and Gandhi, 2015; Nathan, 2003; Truex, 2014), authoritarian elites can make use of such input institutions in order to pursue different goals, including (1) co-opting oppositional and pro-regime elites, (2) gathering information about society, (3) opening up forums for exchange with elites, (4) credibly increasing transparency of government, and (5) deflecting responsibility for unpopular decisions. By comparison with previously studied participatory tools like online petitions or deliberative forums, Internet votes appear to be particularly well suited, as the case analysis has evidenced, to facilitate the co-optation of oppositional and pro-regime elites (goal 1) and the creation and management of offline forums for exchange with elites (goal 3). These goals appear to not be currently pursued by authoritarian elites by means of online petitions or virtual deliberative forums (Balla, 2014; Balla and Liao, 2013; Gunitsky, 2015; Jiang, 2010; Jiang and $\mathrm{Xu}, 2009)$.

To our knowledge, Russia has remained the only authoritarian regime within which political elites have adopted Internet votes as a novel participatory tactic. By contrast, within China's more closed polity, nationwide voting enabled by ICTs was banned in 2007 in order to curb the success of the TV talent show Super Girl. According to Wu (2014), such 'an unprecedented emphasis on the voting power of everyday people, ... lacking in the formal political sphere, alarmed the state' (110). In the Arab world, similar reality TV shows that have featured electoral elements remained on the air despite manifold public controversies around their alleged democratic potential (Kraidy, 2009). Yet, Arab authoritarian leaders have apparently not proactively adopted Internet votes as a participatory tactic.

Why did Internet votes as a novel tactic of consultative authoritarian rule emerge specifically in Russia? At least two characteristics of Russia's semi-authoritarian regime appear to be highly conducive. First, in sharp contrast to China and many Arab countries, Russia has held semi-competitive elections for both the national parliament and the presidency since the early 1990s (Levitsky and Way, 2010). An additional flurry of semicompetitive Internet votes to fill advisory bodies to the government was thus, apparently, not perceived as a major threat by Russia's consultative authoritarian leadership. Second, not only Russia's political regime but also its media landscape was relatively open in comparison with other authoritarian states. Most importantly, unlike its Chinese counterpart, the Russian Internet was not subject to large-scale, systematic filtering for keywords. On the Russian Internet, online votes similar to that for the PCHR had already been conducted by opposition groups to choose speakers at protest meetings and members of a so-called 'Coordination Council of the Opposition' (in press). Internet votes as 
a participatory tool were thus a widely adopted tool, not only in the realm of TV entertainment, as in the Arab world (Kraidy, 2009), but even in politics in a narrow sense, that is, as a tactic in the 'digital repertoire of contention' (Earl and Kimport, 2011: 177) of oppositional groups.

\section{Promising avenues for future research}

Extant research on new online participatory tools adopted by authoritarian governments has largely been grounded in content analyses of the newly opened participatory spaces (cf. Balla and Liao, 2013; Jiang and Xu, 2009), surveys conducted among participants (Balla, 2012, 2014), and survey experiments (Truex, 2014). By contrast, this study has drawn on extensive document analysis and interviews with key actors in order to accomplish an in-depth case study of the power struggle over the design and implementation of one such participatory tool. The analysis presented in this article has thus widened the focus of data collection beyond the content posted on the project websites and data gained from ordinary participants. This was crucial to generating an in-depth understanding of the participatory tool scrutinized here, since, as has been argued, the approximately 108,000 Russian citizens who participated as voters may not even have been the primary political target group at which the entire undertaking was directed (see above). Against this backdrop, the first promising avenue for future research is that of adopting a similar case study approach to scrutinizing participatory tools other than Internet votes (Gunitsky, 2015; Truex, 2014). Why, how, and with what political consequences are different types of online participatory spaces being opened up by political elites in distinct types of authoritarian regimes? Second, this study was the first to investigate the role of Internet votes as a specific type of new participatory mechanism. It would be fascinating to explore, in-depth, whether - and if so, how - authoritarian elites elsewhere are exploiting this seemingly inherently democratic tool to stabilize their rule and innovate consultative authoritarianism.

\section{Acknowledgements}

I owe deep thanks to the Russian human rights activists and experts who participated in this research and to Andrei Zavadski, who conducted the interviews.

\section{Funding}

This research was supported by an Emmy Noether grant sponsored by the German Research Foundation DFG.

\section{Note}

1. All non-academic sources cited in this article, further details on the process of selecting interviewees and analysing the interview data, and the full transcripts of all interviews conducted can be accessed through an Online Supplementary File.

\section{Supplementary Information}

Additional supplementary information may be found with the online version of this article. 


\section{References}

Balla SJ (2012) Information technology, political participation, and the evolution of Chinese policymaking. Journal of Contemporary China 21(76): 655-673.

Balla SJ (2014) Health system reform and political participation on the Chinese Internet. China Information 28(2): 214-236.

Balla SJ and Liao Z (2013) Online consultation and citizen feedback in Chinese policymaking. Journal of Current Chinese Affairs 42(3): 101-120.

Bykhovskaya P (2011) I am Putin's propaganda. OpenDemocracy, 14 December. Available at: http://www.opendemocracy.net/print/63209

Earl J and Kimport K (2011) Digitally Enabled Social Change: Activism in the Internet Age. Cambridge, MA: MIT Press.

Greitens SC (2013) Authoritarianism online: what can we learn from Internet data in nondemocracies? PS: Political Science \& Politics 46(02): 262-270.

Gunitsky S (2015) Corrupting the cyber-commons: social media as a tool of autocratic stability. Perspectives on Politics 13(1): 42-54.

He B and Thogersen S (2010) Giving the people a voice? Experiments with consultative authoritarian institutions in China. Journal of Contemporary China 19(66): 675-692.

He B and Warren ME (2011) Authoritarian deliberation: the deliberative turn in Chinese political development. Perspectives on Politics 9(2): 269-289.

Jiang M (2010) Authoritarian deliberation on Chinese Internet. Electronic Journal of Communication 20(3-4).

Jiang $\mathrm{M}$ and $\mathrm{Xu} \mathrm{H}$ (2009) Exploring online structures on Chinese government portals: citizen political participation and government legitimation. Social Science Computer Review 27(2): 174-195.

Kraidy MM (2009) Reality Television and Arab Politics: Contention in Public Life. Cambridge: Cambridge University Press.

Lagacé CB and Gandhi J (2015) Authoritarian institutions. In: Gandhi J and Ruiz-Rufino R (eds) Routledge Handbook of Comparative Political Institutions. New York: Routledge, pp. 278-291.

Levada (2014) Obshchestvennoe Mnenie - 2014. Available at: http://www.levada.ru/sites/default/ files/om14.pdf

Levitsky S and Way LA (2010) Competitive Authoritarianism: Hybrid Regimes after the Cold War. Cambridge: Cambridge University Press.

Nathan A (2003) Authoritarian resilience. Journal of Democracy 14(1): 6-17.

Noesselt N (2014) Microblogs and the adaptation of the Chinese party-state's governance strategy. Governance 27(3): 449-468.

Oates S (2013) Revolution Stalled: The Political Limits of the Internet in the Post-Soviet Sphere. Oxford: Oxford University Press.

Pearce KE (2015) Democratizing kompromat: the affordances of social media for state-sponsored harassment. Information, Communication \& Society 18(10): 1158-1174.

Renz B and Sullivan J (2013) Making a connection in the provinces? Russia's tweeting governors. East European Politics 29(2): 135-151.

Shevtsova L (2015) Forward to the past in Russia. Journal of Democracy 26(2): 22-36.

Toepfl F (2011) Managing public outrage: power, scandal, and new media in contemporary Russia. New Media \& Society 13(8): 1301-1319.

Toepfl F (2012) Blogging for the sake of the president: the online diaries of Russian governors. Europe-Asia Studies 64(8): 1435-1459.

Toepfl F (in press) From connective to collective action: Internet elections as a digital tool to centralize and formalize protest in Russia. 
Truex R (2014) Consultative authoritarianism and its limits. Comparative Political Studies 1-33. Wu JC (2014) Expanding civic engagement in China: super girl and entertainment-based online community. Information, Communication \& Society 17(1): 105-120.

Yard M (ed.) (2010) Direct Democracy: Progress and Pitfalls of Election Technology. Washington, DC: International Foundation for Electoral Systems. Available at: http://www.ifes.org/publications/direct-democracy-progress-and-pitfalls-election-technology

Yin RK (2014) Case Study Research: Design and Methods. Los Angeles, CA: SAGE.

\section{Author biography}

Florian Toepfl heads the Emmy Noether research group on 'Mediating (Semi-)Authoritarianism: The Power of the Internet in the Post-Soviet Space' at the Free University of Berlin. His research focuses on the inter-relations between old and new media and politics in non-democratic regimes, with a strong focus on Russia and the post-Soviet world. 